\title{
Methods of Inserting a Fistula in the Cecum of Piglings and the Effects of Fistulation on the Flow Rate of Digesta and Digestibility
}

\author{
Kiyoshi Maruta, Seiji Kusuhara and Ichiro Yoshihara \\ Faculty of Agriculture, Niigata University, Niigata-shi 950-21 \\ (Received September 10, 1985)
}

\begin{abstract}
The insertion of a fistula into the cecum of piglings (body weight $10 \sim 20 \mathrm{~kg}$ ) was carried out successfully using two types of fistulae. The first type consisted of a fistula barrel with internal flange, plunger, cushion, two stoppers and screw cap. The second type consisted of an internal washer, fistula barrel, plunger, cushion, stopper, nylon string and screw cap. The former was made of acrylate resin; the internal washer of the latter was made of polypropylene board about $1 \mathrm{~mm}$ thick. The first fistula was fitted into the cecum in an abdominal operation. When the fistula came off spontaneously, the second fistula was fitted without surgical intervention. Piglings with the second fistula grew almost normally in restricted feeding as long as several months. In the flow rate estimations of digesta using a nylon marker, the gastrointestinal contents of fistulated piglings flowed approximately in the same manner as before the operation. Digestibilities in fistulated piglings were similar to before the operation.
\end{abstract}

Jpn. J. Zootech. Sci., 57 (4): 329-335, 1986

Key words: fistula, fistulation, pigling, cecum

For the study of putrefaction and fermentation in the large intestine of piglings, large intestinal contents used to be obtained by the slaughter method. Since these samples could be obtained only once per head, the method was expensive and the sample obtained could be influenced by sampling time and other factors. On the insertion of a fistula in the cecum of pigs, REDMan etal., ${ }^{1}$ HAzEM and DrochneR ${ }^{2)}$, DeCUYPERE et al. ${ }^{3)}$ and NoAKES and CRANWELL ${ }^{4}$ have reported already in detail. Since the body wall of piglings of about $10 \mathrm{~kg}$ body weight is thin and the first fistula (the insertion fistula) comes off habitually, the second fistula (the replacement fistula) is essential, as in the method of DecuYpere et al. ${ }^{\text {s) }}$ The intention in this experiment was to find an easy method of insertion, and to make sure that the second fistula would prevent a leakage of cecal contents and to be able to feed in the metabolism cage. In this method, the first fistula was a universal type and the internal washer of the second fistula was exactly jointed to the groove on the fistula barrel. The influences of fistulation on the flow rate of gastrointestinal contents and the digestibility were estimated. 


\section{Materials and Methods}

1) Fistulae

Two types of fistulae were used. The first fistula consisted of a fistula barre with internal flange, plunger, cushion, two stoppers and screw cap. The second

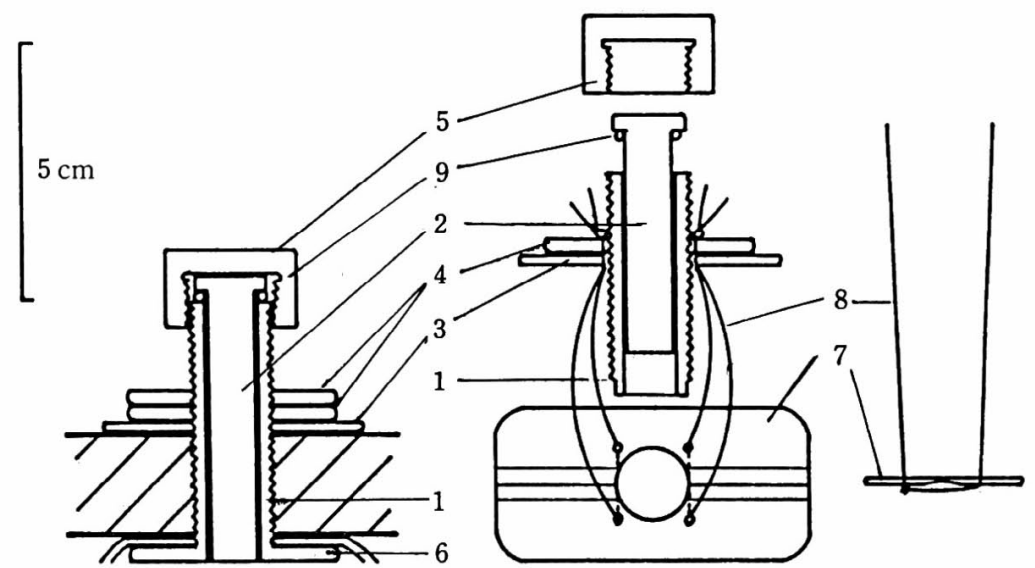

A

B

Fig. 1. Parts and assemblies of the first fistula (A) and second fistula (B) 1. Fistula barrel 2. Plunger 3. Cushion 4. Stopper 5. Screw cap 6. Fixed flange 7. Internal washer 8. Nylon string 9. Gum packing
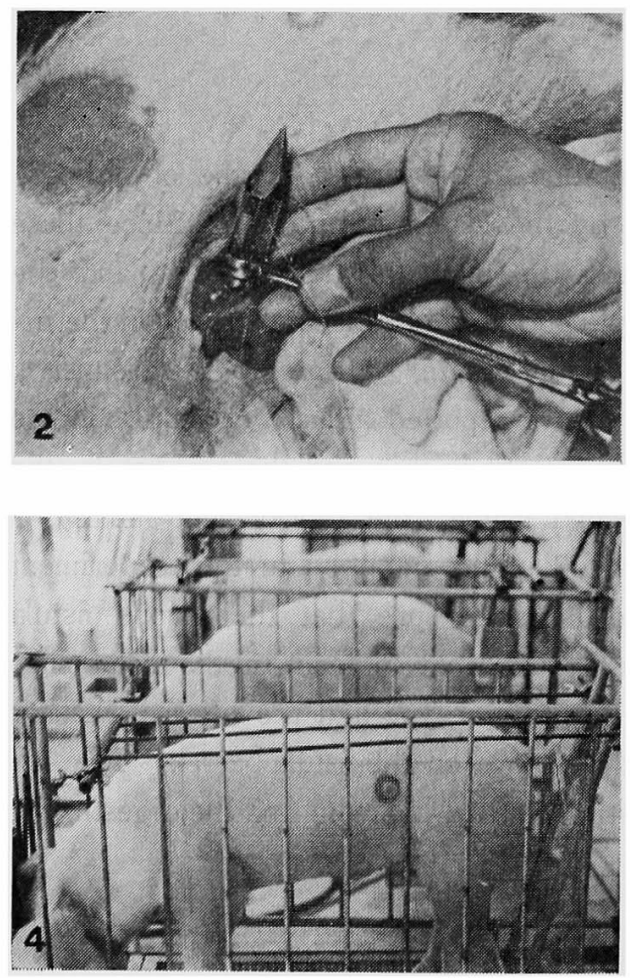

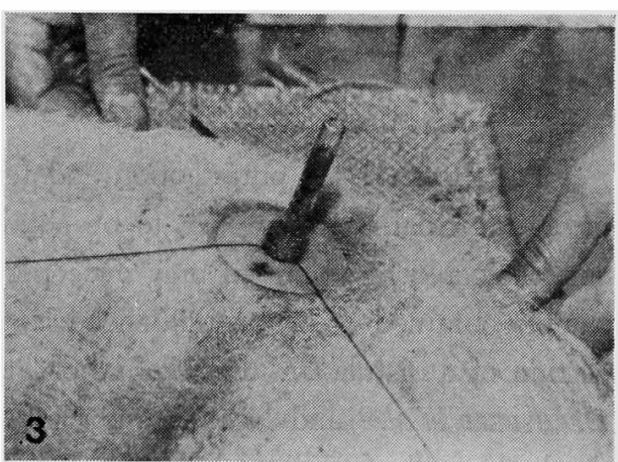

Fig. 2. First operation Trocar and forceps used to hold fistula barrel were set the barrel that was finished purse-string sutures to the cecum.

Fig. 3. Second operation Barrel and cushion were set internal washer in the cecum with guide rod.

Fig. 4. Pigs with second fistula About $50 \mathrm{~kg}$ body weight in 100 days after the first operation. 
fistula consisted of an internal washer, fistula barrel, plunger, stopper, nylon string and screw cap. The fistulae were mostly made of acrylate resin, but the cushion was of polyethylene or polyfluoroethylene fiber board and the internal washer was of polypropylene board. The fistula barrels were $10 \mathrm{~mm} \phi \times 50 \mathrm{~mm}$ in the first fistula, $10 \mathrm{~mm} \phi \times 40 \sim 60 \mathrm{~mm}$ in the second fistula. The internal washer in the second fistula ( $3 \times 6 \mathrm{~cm}, \quad 1 \sim 2 \mathrm{~mm}$ thickness) was made of commercially available plastic. This washer was shaved thinly along the diameter line to fold double at the time of insertion into the cecum. Two pairs of holes $(1 \mathrm{~mm})$ for nylon strings were made on the diameter around the center hole $(13 \mathrm{~mm})$ in the washer. Similar holes were made in the stopper. Parts and assembly of the fistulae are shown in Fig. 1. For the fistulation, forceps to hold the fistula barrel in the first operation as shown in Fig. 2 and a guide rod in the second operation in Fig. 3 were essential.

2) Feeding before and after the operation

The piglings were fed with their commercial formula feed $(20.88 \%$ crude protein, $6.05 \%$ ether extract, $65.14 \%$ nitrogen-free extract, $2.61 \%$ crude fiber, $5.31 \%$ ash, 18. $2 \% \mathrm{DCP}$ and $92.3 \%$ TDN in dry matter) in the amount of $3 \%$ of body weight per day, which was given twice a day, at 9 a.m. and $5 \mathrm{p} . \mathrm{m}$. and water was taken ad libitum. They were given their feed till the day before their operation.

Though water was taken ad libitum, feed was not offered for the first $20 \sim 21$ hours after the operation. A quarter of the fixed amount of feed was given next morning and after that the feed was increased to the previous level within $3 \sim 4$ days.

A small vinyl barn, which was disinfected thoroughly before the operation, was used.

3) The first operation

Piglings of $12 \sim 20 \mathrm{~kg}$ body weight were anesthetized with intermuscular injections of sodium pentobarbital ( $50 \mathrm{mg}$ per $\mathrm{kg}$ body weight) for the operation. The abdomen was opened in parallel to the mid-line $1 \mathrm{~cm}$ to the left of it. The incision was about $8 \mathrm{~cm}$ in length from behind the external urethral orifice; the cecum was exposed. A purse-string suture of 00 plain catgut was placed in the mid-yody of cecum. An incision was made though the wall of the cecum within the area of the suture, through which the flange of first fistula was inserted. After tying with catgut, once again a purse-string suture was performed. The fistula barrel was exteriorized by inserting a sharp trocar through the body wall in the region of the left flank. When a trocar was used, the barrel could be held better with forceps than with the fingers (Fig. 2). A plunger was used to prevent the accumulation of cecal contents in the barrel. The two tips of the catgut used for the purse-string suture were sewed on to the skin. The fistula was held tightly with a cushion and two stoppers. The peritoneum was stitched up with 01 plain catgut, and the skin with no. 8 surgical string. A small amount of tetracycline hydrochloride-powder was used in the abdominal cavity and on the stitched line. Finally $100 \mathrm{mg}$ of oxytetracycline hydrochloride was injected intermuscularly around the fistula and the buttock. There was no need to inject any antibiotic substance after that. 
4) The second operation

In approximately 12 days (occasionally about a month) after the operation, the first fistula came off spontaneously and the second fistula was fitted without surgical intervention. Two pairs of nylon strings (fishing-line no. 12) were run through the internal washer. The nylon strings were each knotted beneath the washer in order to prevent them from slipping out of the washer. With one knot on the right and the other on the left, the washer was folded double and was inserted into the cecum from the lateroabdominal wall through the fistula duct. The inserted washer was opened out flat. A guide rod was inserted through the center hole of the washer (Fig. 3). At this stage, the operation was sure of success. The strings on the knot side were pulled strongly, and the barrel got in the fistula duct was joined positively to the washer. The cushion was slipped on the barrel and strings and then the stopper was screwed to the barrel. when it was screwed tight, nylon strings were run through the holes in the stopper. The barrel was turned counterclockwise while pulling the strings until the fistula was fitted to the pigling's body. Two pairs of strings were tied tightly and the barrel was turned clockwise thoroughly. Hereupon the stopper screwed on the fistula barrel was united to the internal washer joined to the barrel with strings. Before the guide rod is pulled out and the plunger is located in the barrel, the operator must reaffirm that the barrel is joined positively to the washer. Four excess strings were coiled around the barrel and fastened with surgical tape. Once on operator masters this method of fistulation, he will be able to fit the second fistula even while the pigling is feeding. But at first it is necessary to use a slight anesthetic.

5) Digesta flow rate estimations

Flow rate estimations of gastrointestinal contents using a $3 \mathrm{~mm}$ nylon marker ${ }^{5}$ ) were carried out before (body weight, mean \pm s. e. $12.4 \pm 0.6 \mathrm{~kg}$ ) and after (body wight, mean \pm s.e. $18.5 \pm 1.7 \mathrm{~kg}$ ) the operation for 7 piglings. They were fed with their commercial formual feed (chemical composition as in (2)) in the amount of $3 \%$ of body weight per day, which was given twice a day, at 9 a.m. and 5 p. m., and water was taken ad libitum. The marker was administered per os at 9 a.m. and feces were collected at intervals of 3 hours in 5 days. Recoveries of the marker in feces were followed.

6) Digestion trials

Two digestion trials were carried out in order to estimate the effects of the fistulation. Before and after the operation, 2 (body weight, mean \pm s.e. $18.6 \pm 4.4 \mathrm{~kg}$ ) and $3(22.4 \pm 1.8 \mathrm{~kg})$ piglings were used respectively; they were fed with the above feed, to which $0.1 \%$ chromic oxide was added. Other methods were the same as in (5). Since this feed was fed consistently, total feces in 4 days were collected before and after the operation, and chromic oxide and chemical components were determined.

\section{Results and Discussion}

The first fistula came off spontaneously in approximately 12 days after the operation in spite of feeding in a metabolism cage with wire gauze $(5 \times 5 \mathrm{~mm})$. The fistula 


\section{Cecal Fistulation of the Pigling}

duct was gradually increased in size in $7 \sim 10$ days after the operation and the internal flange inserted into the lateroabdominal wall fell off after a few days, because in the first fistula exterior pressure on the fistula was directly transferred with the same force to the fixed flange. Since the second fistula was held with nylon strings, the strings played a buffer action. When the pigling scrubs the second fistula against the cage, the force does not act directly on the internal washer.

The first fistula made of polyethylene was not recommended because the fistula did not come off smoothly. When the fixed flange of the first fistula remains in the abdominal wall, operator needs to pull out the fistula. If the fistula is left as it is, the fistula duct will contract and then close completely. The internal washer of the second fistula made of polypropylene is the best. A washer made of polyethylene or gum is useless, since when the pigling scrubs against the cage, the fistula comes out easily. A thickness of about $1 \mathrm{~mm}$ for the washer is the best. Since a washer $2 \mathrm{~mm}$ in thickness has only slight pliability, the washer will injure the cecal wall and the nylon string will be liable to break easily. Piglings had no fasting time in order to hasten their recoveries in the first operation and to finish the two purse-string sutures while their cecum still contained moderate contents.

From 30 to $60 \mathrm{~kg}$ body weight pigs were fed the raising feed (DCP 15.7\%, TDN $90.8 \%$ in dry matter), and thereafter the progeny tester feed for meat production for pigs in Japan (DCP $12.9 \%$, TDN $70.1 \%$ in air dry matter). In the restricted fe-

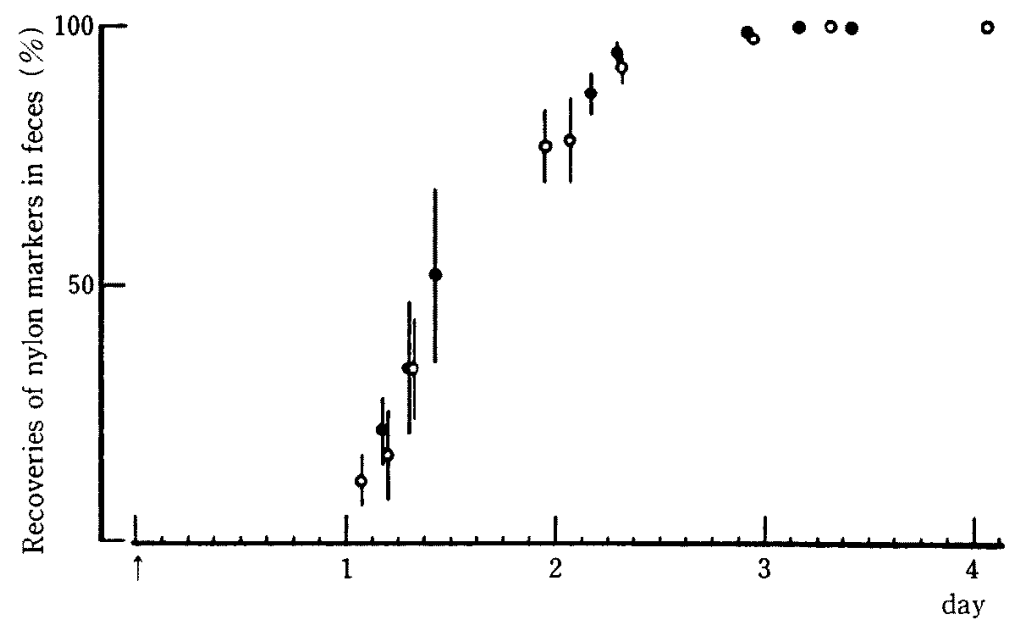

Fig. 5. Recoveries of nylon markers in feces $\uparrow$ : Administered per os at $9 \mathrm{a} . \mathrm{m}$.

-: Before the operation 0 : After the operation

Table 1. Effects of fistulation on the digestibilities

\begin{tabular}{lccccc}
\hline & DM & CP & EE & NFE & CFi \\
\hline Before the operation & $88.6 \pm 1.0$ & $87.7 \pm 2.2$ & $92.1 \pm 2.9$ & $93.4 \pm 0.4$ & $52.1 \pm 0.1$ \\
After the operation & $88.4 \pm 0.6$ & $87.9 \pm 0.7$ & $91.4 \pm 1.0$ & $92.9 \pm 0.7$ & $59.2 \pm 3.8$ \\
\hline
\end{tabular}


eding the fistulated pigs grew almost normally as long as 6 months. In ab libitum feeding the nylon strings of the fistula must be adjusted constantly to the thickness of the pig's lateroabdominal wall. Otherwise, the strings break on account of the rapid growth of the pig's muscle.

Nylon markers administered per os were collected at intervals of 3 hours. Accumulative excreted ratios of the markers in every 3 hours were calculated and are shown in Fig. 5. In the figure, means are plotted only in cases where markers were recovered for more than half of the piglings in every 3 hours. Since excreted patterns differed for an individual piglings and many conditions, the deviation in Fig. 5 grew larger. Recoveries of the marker after the operation were similar to those before the operation. Results show that the gastrointestinal contents of fistulated piglings flow approximately in the same manner as those before the operation.

Results of the digestion trials are shown in Table 1 . On the fifth day before the first feces were collected, bedding was removed. Therefore the preliminary experimental term of the first digestion trial was 4 days. The slightly lower digestibility of crude fiber before the operation should arise from some intake of bedding. Digestibilities of other components after the operation were not different from those before the operation. In any case no unfavorable effects of the operation on digestibilities in a formual feed were shown.

\section{Acknowledgment}

The authors thanks Dr. S. FURUYA for his invaluable advice regarding the cannulation.

\section{References}

1) Redman, D. R., H. S. Teanue, H. K. Henderickx and N. B. King, J. Anim. Sic, 23: 10321035. 1964.

2) Hazem, A.S. and W. Drochner, Z. Versuchstierkunde, 17: 35-40. 1975.

3) Decuypere, J.A., I. J. Vervaeke, H. K. Henderickx and N. A. Dierick, J. Anim. Sci, 46: 463-468. 1977.

4) Noakes, D. E. and P. D. Cranwell, R. Veterinary Sci, 22: 243-250. 1977.

5) Maruta, K. and I. Yoshihara, Jpn. J. Zootech. Sci., 57: - , 1986. 


\title{
子豚の盲腸へのフィステル装着法ならびに消化管内容物の 移動之消化率に対する装着の影響
}

\author{
丸田喜義・楠原征治・吉原一郎
}

新潟大学農学部, 新潟市 950-21

子豚の消化管内での腐敗と醸醉の研究に用いるだめ に，子豚の盲腸へのフィステル装着を試みた。フィステ

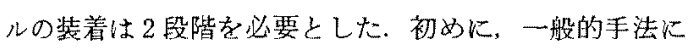
より基本フィステル（アクリル製）を装着する.このフ ィステルが脱落した後に，その拔け出た穴に交換フィス テルを取りつける，その手法は次の上括りである。ナイ ロン゙糸をつけたつばを半分に折りたたんで盲晹内に入 れ，中で開く。これに基本〉ィステルと同径の内简をは めこむ．円筒に叔じこんだ止め其をつばからのナイロン 系で結ぶ、つばはポリプロピレンがよく，厚さは $1 \mathrm{~mm}$
程度が最適である.フィステル部分からの内容物の漏れ はなく，交換つィステルは事故がない限り，代謝っージ で飼育しても長期間に度って交換の必要はなかった。つ ィステルをつけた豚は制限給飭下でほほ正常に成長し た、消化管内容物の流机方は手術前後で差がなく、フィ ステル装着の影響は認められなかった，消化率炕いて も各成分とも手術前後で活とんど差がなく、フィステル 装着の影響は認められなかった。

日音会報, $57(4) ： 329-335,1986$ 